\title{
Direito e poder
}

\author{
Carl Schmitt \\ (Tradução e notas introdutórias por Alexandre Franco de Sá)
}

\section{Três notas introdutórias}

1. O artigo, cuja tradução portuguesa seguidamente se reproduz, intitulado originalmente Recht und Macht, constitui o primeiro capítulo do mais importante livro de juventude de Carl Schmitt: O Valor do Estado (Der Wert des Staates). Publicado em 1914 e apresentado posteriormente, em 1916, como Habilitationsschrift na Universidade de Estrasburgo, a circunstância de Schmitt voltar a publicar o primeiro capítulo de $O$ Valor do Estado, de novo, em 1917, agora como artigo publicado na Revista Summa, permite-nos concluir que Schmitt atribuía grande importância a essa obra. Uma tal importância, porém, não deixa de ser surpreendente, se dedicarmos atenção ao carácter escolar da exposição e à posição neokantiana que está subjacente a todo o percurso das suas reflexões, bem como ao contraste que, nesse sentido, a caracteriza, pelo menos sob um ponto de vista formal, em relação ao decisionismo assumido por Schmitt na década de 1920. Dir-se-ia que, ao contrário do que se poderia esperar, ou seja, ao invés de considerar $O$ Valor do Estado como um texto de juventude no qual o tema da natureza do Estado, bem como o da relação entre direito e poder, seria tratado ainda de modo ingénuo e insuficiente, Schmitt considera o seu livro de 1914 uma referência fundamental para a consideração do posterior desenvolvimento do seu pensamento. Na sequência do reconhecimento pelo próprio Schmitt da importância desse livro, procurei analisar não apenas de que modo é possível considerar nele já uma antecipação do decisionismo, mas também - e mais importante - de que modo se pode encontrar, nas teses formuladas a partir de 1914, uma fonte essencial para a consideração do verdadeiro alcance das teses decisionistas, desenvolvidas por Schmitt, de forma ex- 
plícita, sobretudo após a publicação de A Ditadura e Teologia Política, respetivamente de 1921 e $1922^{1}$.

2. No presente texto, Schmitt apresenta explicitamente uma posição neokantiana na abordagem da relação entre direito e poder. Partindo da dicotomia entre ser e dever-ser, entre Sein e Sollen, ou entre facticidade e normatividade, Schmitt estabelece o direito e o poder como pertencentes a dimensões diferentes que, como tal, não podem ser relacionadas diretamente. Segundo o Schmitt de Direito e Poder, o direito pertence a um plano normativo e o poder a um plano fáctico. Tal quer dizer que, à medida em que facticidade e normatividade não se influenciam nem se determinam entre si, o direito não pode ser compreendido aqui como uma consequência do poder, nem o poder como causa de algo valer como norma. Não é pelo facto de uma norma ser ou não cumprida facticamente, ou ter ou não ter força ou poder fáctico para se impor, que uma norma deixa de ser válida na sua normatividade: ela é norma não por ser cumprida facticamente, mas por dever sê-lo independentemente do que se passe no plano da realidade fáctica. E, a partir desta dicotomia radical, Schmitt contesta, no presente artigo, aquilo a que chama uma Machttheorie, uma "teoria do poder" caracterizada por estabelecer a norma como o resultado da força ou do poder fáctico capaz de a impor como tal. Para Schmitt, a "teoria do poder" deveria ser invertida numa "teoria do direito", numa Rechtstheorie, para a qual a vigência fáctica das normas, ou a capacidade de uma determinada ordem jurídica reunir o poder fáctico suficiente para impor a sua vigência, seriam possíveis não porque um poder fáctico causaria

1 Cf., neste sentido, sobretudo os meus artigos "Sobre a justificação racional do poder absoluto", "A Coerência de Carl Schmitt" (recentemente republicados no meu livro Poder, Direito e Ordem: ensaios sobre Carl Schmitt. Rio de Janeiro: Via Verita, 2012, pp. 13-44 e 213-244) e "The Event of Order in Carl Schmitt's Thought and the Weight of Cirumstances", in Telos. $\mathrm{n}^{\mathrm{o}} 147,2009$, pp. 14-33. 
as normas na sua validade normativa, mas porque o poder fáctico do Estado, ao realizar o direito, seria já uma manifestação da validade intrínseca das normas jurídicas, isto é, do dever-ser que as constituiria na sua normatividade.

O conceito de Estado aparece, para o Schmitt do presente texto, como a instância mediadora que permite a ligação entre a normatividade do direito e a facticidade do poder. Tal quer dizer que, aqui, o Estado emerge a partir do direito e é, nesse sentido, por ele determinado. Como Schmitt afirma explicitamente, não é o Estado que causa o direito, nem as normas jurídicas são o resultado do exercício pelo Estado de um poder fáctico e violento, mas passa-se exatamente o contrário: é o direito que, na sua normatividade ou, o que é o mesmo, no dever-ser que o determina, possibilita que exista uma realidade como o Estado. O Estado é, então, a instância pela qual o direito se realiza e encontra o plano fáctico. E, nesse sentido, o Estado é a condição de possibilidade não do direito (Recht), mas daquilo a que, em Teologia Política, Schmitt chamará a "efetivação do direito" (Rechtsverwirklichung). Assim, pode-se dizer que o Estado é, enquanto condição da efetivação do direito, ou seja, enquanto condição da realização do direito no plano da facticidade, a realidade que torna presente e visível facticamente o direito, e que ele é esta presentificação fáctica do direito na medida em que o direito é a condição cuja existência (no plano normativo) o torna possível enquanto Estado. Por outras palavras, poder-se-ia dizer, usando uma relação de matiz kantiano, que, para o Schmitt de O Valor do Estado, o Estado é a ratio cognoscendi do direito, e que o é precisamente porque o direito é a imprescindível ratio essendi subjacente ao próprio Estado.

3. A relação que o jovem Schmitt estabelece entre direito e poder, ou entre o direito enquanto normatividade e o Estado que o efetiva, constitui uma estrutura fundamental que se mantém no pensamento schmittiano ao longo da década de 1920, aquando da elaboração da sua teoria decisionista. Em larga medida, a dicotomia entre direito e poder, nos traços fundamentais que regem a 
articulação dessas duas instâncias, reproduz-se na dicotomia decisionista entre direito e decisão. Quando Schmitt esboça o seu decisionismo ao insistir na irredutibilidade da decisão à norma, quer por a norma carecer de uma decisão anterior que a estabelece, quer por a norma não poder determinar integralmente a decisão concreta que a aplica, a base para esta abordagem encontra-se na ideia, esboçada em 1914, de que o exercício do poder fáctico no plano político - o exercício do poder do Estado ou de uma decisão fáctica que manifesta o político - torna-se possível na medida em que tal exercício é uma efetivação do direito ou de uma ordem que se lhe encontra subjacente como sua condição de possibilidade. Se, em Teologia Política, Schmitt insiste na não determinação da decisão pela norma, se o decisionismo se apresenta como a tese segundo a qual a norma jurídica não pode absorver o momento da decisão, essa defesa decisionista de que o direito não pode ser pura normatividade, abarcando sempre o momento da decisão que remete para o plano fáctico, tem na sua base o vínculo da decisão a uma ordem que não se esgota na simples normatividade. Assim, se é verdade que, no decisionismo, a decisão se afirma como momento irredutível à norma, e anterior a esta mesma norma, à medida que, segundo Schmitt, se pode constituir como decisão soberana, decidindo o "estado de exceção", também é verdade que essa decisão da exceção só ocorre em nome de uma ordem, em nome de um salus populi ou da conservação do Estado, que é a condição de possibilidade de que uma ordem normal possa vigorar.

Todo o conceito de exceção, no decisionismo, se organiza em torno da ideia paradoxal de uma decisão que se subtrai à sua determinação pela norma em nome do restabelecimento da ordem com base na qual essa mesma norma possa vigorar, ou seja, de uma decisão que suspende a norma não para a aniquilar, mas para que possa continuar a vigorar. Dir-se-ia, por outras palavras, que - como Schmitt afirma explicitamente em Teologia Política - a suspensão da ordem jurídica normal no "estado de exceção" não é uma anomia, uma pura destruição das normas ou uma simples ausência da ordem, mas um modo particular de esta 
ordem estar presente. Dir-se-ia, noutros termos, que, na exceção, a ordem está não propriamente ausente, mas presente paradoxalmente enquanto ausente, através da suspensão da própria normalidade ou da vigência normal das normas jurídicas. Dir-se-ia, por outras palavras, que a ausência da normalidade é aqui uma presença paradoxal da ordem. E é essa relação entre ordem e exceção que adquire a sua plena inteligibilidade precisamente a partir da relação entre direito e poder que Schmitt estabelece no artigo que agora se apresenta. Do mesmo modo que o direito se manifesta no poder fáctico do Estado, e que o Estado é não a causa do direito, mas a presença que torna presente, como uma mediação, esse mesmo direito no plano fáctico, assim também a decisão é a mediação da ordem, a ratio cognoscendi na qual a ordem se torna presente, ordem essa que não pode prescindir da decisão fáctica como sua ratio cognoscendi, ou da existência da soberania como a instância na qual a própria ordem não pode deixar de se tornar visível e de se tornar facticamente existente.

\section{DIREITO E PODER}

\section{Carl Schmitt}

Se a opinião de que todo o direito é apenas um resultado de relações factuais de poder, assentando, em última análise, na violência, pudesse experimentar uma análoga transposição para o âmbito das opiniões científicas, a pergunta pela relação entre direito e poder estaria já decidida. Pois é tão grande o número daqueles que, em confrontações plausíveis e com numerosos exemplos da história e do quotidiano, dão ao direito um fundamento unicamente fáctico, que eles têm indubitavelmente a preponderância, enquanto apenas for tida em conta a disseminação fáctica da sua opinião. No entanto, logo que os fundamentos e a sua correção forem testados, esta factualidade já não é tida em consideração e já só apenas argumentos decidem a questão.

A oposição das duas teorias que são assinaladas através da antítese entre direito e poder não é pura e simplesmente con- 
ciliável. Se o direito, através da teoria do poder, for concebido como resultado de uma determinada repartição de forças sociais, e se o seu conceito para a filosofia do direito puder ser adquirido através de uma explicação de acontecimentos históricos aos quais é remetido um julgamento ligado à representação daquilo que é conforme ao direito, então, objetivamente, permanece indiferente se a supremacia de que sai o direito é uma supremacia puramente física ou psíquica. Os peixes grandes, que, segundo o conhecido ditado, têm o direito de devorar os pequenos, e a classe socialmente dominante que, pelos efeitos de uma submissão de há séculos dos habitantes originários de uma terra, estão aptos a determinar as leis no seu conteúdo, têm ambos direito apenas porque têm o poder. O quanto, dentro do poder, enfatizam-se infinitamente finas diferenciações não está em questão para uma consideração filosófica que consiga chegar à diferença principal. $\mathrm{O}$ poder do assassino face à sua vítima e o poder do Estado face ao assassino não são, para a teoria do poder, diferentes segundo a sua essência, mas apenas na sua manifestação exterior, condicionada por um desenvolvimento histórico, no seu alcance, na sua impressão sobre as massas dos homens. A essa concepção resta apenas investigar o quanto, com remissão a esses acidentes que pertencem também à factualidade, o conceito de direito deve ser mais detalhadamente delimitado, e como o específico do poder do Estado deve ser determinado face ao poder do assassino. Na medida em que a teoria faz referência à consequência, este específico só se pode igualmente encontrar no âmbito da factualidade puramente empírica e não pode ser posto em contacto com uma "legitimação" em sentido particular. Seria possível, portanto, punir o poder do Estado, fundá-lo, na sua diferença em relação a qualquer outro poder, na intuição geral dos membros do Estado, e dizer que o Estado tem o consentimento dos homens para si quando exerce, desse modo, o seu poder; contudo, o consentimento que dá um cunho particular ao seu poder assenta no facto psíquico do acordo com a maioria e carimba a supremacia fáctica como autoridade, o poder como direito. A opinião corrente pensa a pergunta pelo fundamento do direito de tal modo que, no final, quando se 
pergunta sempre de novo pelo direito do direito, o seu fim é o regresso a um facto. Isso é completamente consequente logo que, para a explicação do direito, se trouxer à consideração apenas o acordo dos homens ou um outro processo factual. Pois também os momentos que remetem para o consentimento ou o não consentimento dos homens ou de determinados grupos sociais são aí empregues unicamente como factos psíquicos, não porque sejam corretos, mas porque existem. O direito é, assim, para os teóricos do poder, apenas uma parte do ser que não se pode explicar para além disso nem de outro modo, que não se pode justificar de outro modo que não como um ser qualquer, de particular interesse por causa do seu significado imediato para os homens e para a sua vida em comum, mas completamente inserido no mecanismo do acontecer fáctico, do qual não se destaca em nenhuma parte.

Daí que, para esta teoria, não haja qualquer refutação da legitimação de um poder. A quem lhe estiver submetido não ajuda que ele esteja aí, com os seus argumentos, como um pobre tolo, e vinculis ratio cinatur. Talvez isso esteja mais bem escondido na terminologia, talvez se queira dizer que na alternabilidade inescapável com a qual o poder do direito resulta do direito do poder teria de ser abalada uma contraposição separadora no sentido de uma prevalência do direito na irrefutabilidade de um facto; numa expressão popular diz-se que uma mão cheia de violência vale mais que um saco cheio de direito, e num modo de falar banal fala-se hoje da lógica dos factos. O sentido é sempre o mesmo: cada evocação de um direito contém a remissão a um poder; cada esforço por ajudar um direito a ser reconhecido significa um anseio de poder; os argumentos com os quais um direito é demonstrado são apenas cálculos sublimados da possibilidade de se impor; a sua força demonstrativa é igual à força persuasiva em dado instante.

Se o direito for considerado como algo que por uma vez existe, ele subordina-se à lei da causalidade como tudo o que existe. Se o direito se tornar poder, esfuma-se em nada qualquer outra explicação que não uma explicação causal, e qualquer causa que evoca um efeito se torna, nessa medida, poder e, com isso, 
novamente direito. Mesmo quando o facto em que desemboca, em última análise, o regresso acerca do fundamento do direito for recuado tão remotamente para o passado, este curso de pensamento permanece inteiramente numa teoria que unicamente quer e pode constatar e explicar, mas não justificar ou fundamentar.

Ao contrário disso, para a teoria do direito, uma remissão à opinião da maioria dos homens que pensam de modo decente e consentido significa uma referência a algo que não é válido a partir de uma autoridade própria, mas designa apenas um conteúdo que corresponde àquilo que deve ser. Uma consideração mais exata desta remissão é particularmente instrutiva para a apresentação da oposição de ambas as teorias. Se a lei positiva encontrar uma tal alusão, pode ser controverso se, com isso, a opinião dos homens decentes se torna parte da lei positiva, influenciando a lei, ou se se alude a um complexo autónomo de normas que é independente em relação ao direito e que também permanece assim quando a lei se lhe referir. Se a lei positiva for direito porque, através do meio de determinadas formas, é uma intuição dominante que se pode trazer à validade, então a alusão da lei à intuição dominante significa um regresso à própria origem, ao estado de natureza; a intuição dos homens que pensam de modo decente e consentido é paradigmática porque os homens decentes estão em maioria e se impõem com a sua opinião, que valeria porque domina. A sua validade não se basearia em que são os homem decentes que a representam, mas em que estes homens se podem designar como decentes sem experimentarem contradição eficaz e têm poder para criar o reconhecimento da sua opinião. Na mais rigorosa oposição a isso, todavia, também nas palavras "decente e consentido" se pode encontrar o fundamento de validade, de tal modo que as intuições às quais se alude obtêm uma dignidade própria; elas são válidas, então, apenas enquanto merecem os dois honrosos predicados, mas também são válidas quando a maioria dos homens virem as coisas de outra forma, e mesmo quando já não houver mais nenhuns homens decentes. Elas não são o resultado de um efeito conjunto dos homens e das suas opiniões, elas não se dão a partir de factos, mas a partir de argumentos. Tam- 
bém a circunstância de que não se fala abstratamente daquilo que é decente e consentido, mas dos homens que pensam de modo decente e consentido nada conseguiria mudar nisso e teria apenas o significado de facilitar a verificação daquilo que é decente e consentido. A opinião dos homens não seria o fundamento de validade, mas antes indício de um valor.

A questão não é se o direito ou o poder acontecem no mundo, mas se o direito pode ser extraído a partir de factos. Também o reconhecimento do direito pelos homens é unicamente um facto, e pergunta-se precisamente se factos conseguem fundar um direito. Se a questão for negada, então dá-se a oposição de dois mundos. Se o direito se tornar, em relação ao poder, autónomo e independente, segue-se daí um dualismo que corresponde às antíteses entre dever-ser e ser, entre consideração normativa e genética, crítica e científico-natural. A esfera do direito não pode aí ser encerrada com o âmbito do direito positivo, que vale factualmente, mas se a validade factual for acrescentada ao direito, para constituir a sua positividade, ela é acrescentada como algo exterior, como algo, neste sentido, inessencial. Quem estabelece a afirmação de que todo o direito é necessariamente positivo, quem encerra a fundamentação do direito com os acontecimentos "que criam" direito positivo, confessa-se, com isso, da teoria do poder e nega a oposição inconciliável entre direito e facto, e a frase: non potest detrahi a jure quantitas. $\mathrm{O}$ direito, que nada deve ter a ver com uma explicação factual, recebe num mundo próprio uma autonomia que em nenhuma parte é interrompida. Mas se o direito se tornar poder, isto é, um simples facto, ele não se poderá elevar, em nenhum lugar, acima da factualidade; em cada execução singular do direito não se pode falar de raciocínios e argumentos, mas apenas de factos, e tudo aquilo que, de cada vez, foi levado a cabo como "fundamentos" de uma decisão dissolve-se num enorme argumentum ab utili velado. Também não pode ser demarcada como simples poder, dentro da teoria do direito, uma área que permaneça reservada a um tratamento através de construções jurídicas e de perguntas por aquilo que, de forma consequente, daí teria de resultar. Não é, portanto, exequível declarar-se de acordo 
com o método corrente que funda um complexo de normas que o Estado, enquanto poder particular, emana unicamente na vontade fáctica deste Estado, mas que, dentro deste complexo, trabalha com os meios da argumentação jurídica e quer intermediar a vontade racional e correta, embora o fundamento de validade da norma seja um fundamento meramente factual. Um facto não se deixa demonstrar, uma vontade não se deixa mostrar como presente por ser mostrada como racional e correta. Para ninguém mais do que para o jurista são importantes os ataques de Kant à prova ontológica de Deus.

Se o direito for definido como poder, ele já não é essencialmente norma, mas essencialmente vontade e fim. $\mathrm{O}$ direito que é factualmente válido é, então, uma soma de determinadas prescrições que resultam de um lugar que estabelece fins, e um julgamento do direito só é possível de tal modo que os fins sejam adequados uns aos outros. É inteiramente manifesto que o direito não precisa de mais nenhuma fundamentação e que também não é capaz dela, na medida em que se tornar numa vontade, num fim, do qual uma realidade como o Estado quer que seja alcançado. Com esse fim, pode-se, então, comparar certamente todos os outros fins possíveis, mas quando o direito, segundo o seu conceito, está numa qualquer relação com a realidade que estabelece fins, uma tal comparação e um tal julgamento dos fins é juridicamente irrelevante, pois a factualidade, que é introduzida no direito através do fim e do Estado não se pode refutar. O princípio vivificante no mundo do direito não seria a argumentação jurídica na sua correção, mas a vontade do Estado na sua factualidade concreta.

Dito rigorosamente - e a filosofia só pode tomar tudo rigorosamente -, ambos os mundos do direito e do poder têm de estar um junto ao outro numa autonomia inconciliável. A teoria que unifica o direito, num ponto qualquer, com o poder teria de renunciar, de um modo consequente, a qualquer explicação que não uma explicação causal, teria de dissolver todo o direito e toda a norma jurídica num jogo de forças que empurram ou travam, no qual uma valoração ou um pathos do consentimento ou não consentimento seria sem sentido - ou não sem sentido, 
pois, nesta qualificação, já está contido novamente um não consentimento. Apesar de aquele que concebe uma intuição nas suas últimas consequências só a elas as compreender corretamente, e de quem expressar uma opinião não se referir ao seu conteúdo de representações factuais e poder objetar ao adversário uma má compreensão quando ele mesmo, com uma consequência corretamente consequente, não estiver de acordo, é contudo útil, para a clarificação da questão, incluir na consideração os conteúdos de representação não declarados, mas atuantes. Nomeadamente, é possível ouvir da definição do direito como poder uma valoração que parece depender do conceito de poder, na medida em que, pelo menos, cada poder relativamente duradouro e consistente é concebido como legítimo e fundado - não meramente explicável. $\mathrm{Na}$ confiança de que há as suas boas razões quando precisamente esta e nenhuma outra proposição se pôde desenvolver como poder de uma norma jurídica, ou quando precisamente essa vontade alcança uma posição autoritária, direito e poder são simplesmente identificados, sob a omissão tácita da pergunta que unicamente é importante acerca das "boas razões". Uma tal confiança no curso das coisas e na justiça da história expressa-se, por exemplo, nas palavras do escrito de Lutero de potestate Papae: Primum, quod me movet, rhomanum pontificem esse aliis omnibus superiorem, et ipsa voluntas dei, quam in ipso facto videmus. Neque enim sine voluntate dei in hanc monarchiam unquam venire potuisset rhomanus pontifex. Como, nesta recondução de um poder factual à vontade de Deus, encontra-se o reconhecimento de uma legitimação, o reconhecimento das boas razões contém um consentimento e uma valoração, do mesmo modo que o salientar da não acidentalidade de um resultado histórico expressaria um óbvio carácter supérfluo sem uma tal valoração.

Na palavra poder encontra-se, para ter em conta as associações que hoje se lhe ligam, um momento de respeito reconhecedor, através do qual se torna possível fazer do direito uma espécie particular de poder, uma supremacia consciente, tal como é tacitamente pressuposto quando a frase acerca dos peixes grandes que têm o direito de devorar os pequenos é recebida, geralmente, 
como paradoxal. Com a elevação do poder ao âmbito do agir humano consciente de fins já está empreendida uma distinção, pois o homem consciente e consciente de fins é precisamente, para o utilitarista, um ser de preferências - desde logo porque o honroso predicado da consciência de fins só pode ser garantido quando se trata de fins que se tornaram conscientes para o próprio observador. Mas, se mesmo o momento mais fraco de uma valoração alcança aquilo que no direito é específico face ao poder, se o direito aparece, independentemente de qual seja o ponto de partida, como um poder preferido, então ele torna-se qualitativamente diferente do poder e transforma a sua essência. Os predicados nos quais a particularidade do direito é encontrada introduzem, nas suas consequências, uma exata inversão das antíteses: não é o direito que é explicado a partir do poder, mas o poder a partir do direito. O poder que é procurado para a definição do direito só se pode ele mesmo compreender a partir de um direito, ele é um tal poder apenas porque o é "com direito". Quando, em vista de um qualquer acontecimento, é dito que quem tem o poder tem também o direito, aquilo que para um completo cepticismo significa uma negação do direito torna-se, na mesma expressão literal, no testemunho da mais elevada confiança e diz que nenhum poder se impõe a não ser que esteja legitimado. Precisamente aqueles que comparam a relação entre Estados e classes humanas entre si com a dos homens singulares no estado de natureza salientam de bom grado que não é nenhum acaso quando estes Estados ou raças determinadas se superiorizam, e outros se afundam numa ausência de poder e de direito. Nisso é apenas de admirar que ainda ninguém tenha tentado abordar o problema de outro lado e, por exemplo, estabelecer uma estatística dos assassinados. Assim como não é um acidente que precisamente este homem seja assassino, assim também não é um acidente que precisamente o outro seja o assassinado.

Há gente para a qual a adequação geral dos homens em julgamentos jurídicos importantes não parece significar outra coisa senão a uniformidade com a qual hoje, na Alemanha, muitas centenas de milhar, a seguir ao almoço, têm a necessidade 
de beber café. Mas ainda nenhum desses utilitaristas conseguiu determinar o momento histórico em que, para além do "egoísmo", veio a grande iluminação e ele se elevou, com a sua própria força, acima da terra rasteira, para pairar numa esfera na qual tem de reconhecer o egoísmo do outro como "igualmente legítimo" e de se lhe abandonar. Num tal processo, poder-se-ia ter dado que homens espertos singulares estivessem aptos a incutir a sua visão nos outros - um pouco como o grande Frederico moveu os camponeses bávaros para o cultivo da batata - e a introduzir, através da sua supremacia factual, um estado pelo qual se tornou possível submeter o egoísmo não esclarecido a um egoísmo esclarecido e, deste modo, segurar a rédea de que persista uma ordem tolerável. Stahl tem razão quando afirma (Philosophie des Rechts, I, p. 240): "se se desenhasse previamente a um homem que nada soubesse do Estado o movimento da vida do povo, que se precipita em incontáveis direções, o constante mover-se contra o Estado - pois todos os interesses do singular são contra ele e contra a sua ordem -, ele acreditaria menos na possibilidade do Estado do que agora a maior parte da gente no reino eterno". Aquilo que aí é dito do Estado vale para qualquer racionalidade, esclarecimento, correção ou como se the queira chamar. No final, a melhor visão, que, como tal, vincula os homens, só pode ser não porque é a mais poderosa, mas porque é a melhor. Á, contudo, a fundamentação assenta numa valoração que já não é empírica. A valoração também não é dissipada através de que só se chama melhor à visão que permanece sobrevivente como resultado de uma seleção no combate das opiniões e no curso do tempo; pois qualquer teoria da seleção evolucionista já tem de partir de valores e de pressupor valores, pois, na afirmação de um desenvolvimento sem meta, se encontra uma contradictio in adjecto. A meta necessária para cada desenvolvimento não pode dar-se a partir da consciência daquilo que se desenvolve ou a partir da sucessão de acontecimentos dos quais se esclarece que significam um desenvolvimento, mas apenas da consideração consciente daquele que concebe a sucessão como desenvolvimento. 
Do mesmo modo, o empírico, que vê em todo o direito apenas um jogo de interesses e diferencia interesses predominantes ou dignos de proteção, esconde o problema em equivocidades indiferenciadas. A palavra interesse contém a oposição a qualquer norma e deve permanecer explicitamente naquilo que é factual, conforme a experiência; se ela entrar na definição do direito, então a norma, que está para além de todos os interesses, deve ser com isso eliminada. O não direito, que pode ser definido como um ferir de interesses, aparece aí como aquilo que é primário. $\mathrm{O}$ fundamento desse primado segue-se a partir de um Faktum puramente empírico: primeiro tem de ser ferido um interesse, antes que os homens cheguem ao pensamento de o proteger. Por exemplo, tem de acontecer primeiro o ferir dos interesses que se encontra num assassínio, antes que se possa dizer que a vida é um interesse protegido e que haja uma norma segundo a qual o assassínio é algo reprovável. O protótipo de toda a ação jurídica seria, por isso, a ação de defesa contra um ataque que se eleva e enobrece do instinto de vingança do selvagem à defesa social. Em semelhantes cursos de pensamento, a ocasião psicológica de se tornar consciente da norma mistura-se com o fundamento de validade, e a teoria passa para uma explicação causal da norma a partir do facto psíquico da habituação. A representação do ferir de interesses que predomina em tais desempenhos e unicamente produz a aparência da fácil compreensão, contém constantemente, no entanto, um elemento normativo que é descoberto ou no "interesse" ou no "ferir". Não é qualquer um que é sujeito adequado de um interesse; juridicamente, não se considera como um ferir dos interesses do animal quando ele é abatido. Portanto, pergunta-se quem decide sobre se está presente um ferir de interesses, o supostamente ferido ou uma instância superior. Se se pensar o homem numa comunidade e se falar em que, num caso concreto, se deu um ferir de interesses ao qual a comunidade reage, então o juízo foi retirado do singular ferido. Contudo, a comunidade não julga sobre o interesse próprio ou sobre o interesse subjetivo do singular que no caso concreto é ferido, ela nunca se dá como juiz em causa própria, mas refere-se a uma norma "objetiva". De 
nenhum modo seria possível ao mundo que os interesses destilassem a partir de si a norma com a qual eles poderiam ser ponderados e classificados. A muito mencionada comparação do Barão de Münchhausen, que se tira a si mesmo do pântano pelos cabelos, não atinge aquele que quer tornar a norma independente do interesse, mas precisamente aquele que a extrai do interesse que ele submete à norma. Se o interesse da comunidade ou da coletividade decidisse as coisas unicamente enquanto tais, como aquilo que é mais forte, então a colisão de interesses subjacente à decisão seria igualmente uma colisão de interesses da coletividade; essa decidiria sobre isso como um partido, e o seu direito seria, na verdade, apenas poder, ela imiscuir-se-ia como participante num ferir de interesses do singular e imporia o seu interesse. Nisso, encontrar-se-ia uma consideração consequente. Mas, se apenas os interesses desta coletividade ou aqueles que são por ela protegidos forem observados como dignos de serem designados como interesse, se os interesses da coletividade forem mais importantes do que os dos singulares, se eles estiverem obviamente mais altos do que aqueles e se for uma desgraça que eles sejam sufocados pelos interesses singulares, então o fundamento da supremacia dos interesses coletivos não se pode deduzir do simples interesse. Também aqui o interesse, tomado rigorosamente, se torna num interesse legítimo, e já não se fala do facto nu.

A teoria que explica o direito como facto vê-se sempre de novo deslocada para o ponto onde tem de diferenciar entre um poder que é capaz de se tornar direito e um que é incapaz disso, entre um egoísmo esclarecido e um egoísmo estúpido, entre um egoísmo capaz de desenvolvimento e não capaz de desenvolvimento. "Capaz" quer dizer aqui apenas "ter valor de", também a contraposição entre interesse singular e coletivo contém apenas valorações que possibilitam "elevar" o poder a direito. A definição do direito começa quando o poder se torna indiferente; e não pode ser extraído nenhum contra-argumento de que se se recusa a retirar as consequências até ao ponto em que a inconciliabilidade se torna patente. Em cada negação da legitimação do direito, tal como a que está contida na definição como poder, esconde- 
-se a ousadia de demonstrar, para isso, a legitimação do poder; a definição não diminui o direito, mas eleva o poder, ela só foi possível porque o poder já antes tinha sido pensado como direito. A perplexidade do esforço de misturar num círculo determinado por normas, tal como o direito significa, factos empíricos, tais como são compreendidos como poder, encontra a sua circunscrição esclarecedora na possibilidade de, contra a afirmação de que o direito é sempre poder, estabelecer a afirmação contrária, a de que o poder seja sempre apenas direito, sem que se tenha de pensar numa refutação.

Se deve haver um direito, então ele não pode ser extraído do poder, pois a diferença entre direito e poder não pode pura e simplesmente ser ultrapassada. Ninguém designará como norma o opinar de um homem singular; da essência da norma faz parte que ela seja válida independentemente do singular (em sentido filosófico). Para a norma, não há qualquer singular que a pudesse constituir ao percepcioná-la, mesmo que esteja em questão a correção lógica ou jurídica. Mas se o opinar do singular não pode fundamentar nenhuma norma, tão pouco o podem dez ou centenas de milhares de singulares, pois a soma não se consegue elevar, por uma força própria, acima da espécie daquilo que é somado. É natural, precisamente aqui, falar de que há um ponto no qual a quantidade se transforma na qualidade. No entanto, nos casos em que se poderia assumir uma semelhante metamorfose, trata-se sempre apenas de que a extensão da quantidade é concebida como forma de manifestação, como símbolo ou indício de uma qualidade, e de que a grande massa que se impõe remete, na sua impressão sobre o observador, para algo de extra-mundano, extra-humano e intemporal. O efeito psicológico de grandes espaços e da extensão temporal, a sublimidade de construções colossais são exemplos de tal apresentação da qualidade através da quantidade. Com isso, no entanto, nada se mudou na essência, pois o sem sentido nunca pode crescer até um sentido, aquilo que é estranho ao valor nunca pode crescer até um valor. Uma passagem gradual é completamente impensável; usá-la para a fundamentação de valores jurídicos ou éticos quereria dizer trocar a pergunta pelo 
surgimento de uma realidade com a pergunta pelos sintomas de um valor, pelo qual pode passar, frequentemente, a extensão da quantidade. Se a diuturnitas, o longum tempus for um sinal de que algo encontrou reconhecimento como valor, e se se encontrar aí uma praesumtio facti para o carácter fundamentado desse valor, a fundamentação do valor não é reconduzida a uma investigação de factos quando se recorre ao curso cômodo de uma gradação do acontecer factual que se joga em espaços de tempo infinitos, e que só pode ser demonstrada, nas suas etapas singulares, de um modo inteiramente sumário. A estalactite precisa de séculos e séculos até se ter tornado numa figura vistosa, mas os minerais dos quais ela se forma têm de sempre ter estado factualmente presentes e nenhuma estalactite se formaria de uma pura ligação entre oxigênio e hidrogênio, mesmo em milhões de anos.

"A eternidade não se eleva por si" (Däubler, Das Nordlicht, II, p. 533). Da consideração da natureza à qual também pertence a vida em comum dos homens, enquanto ela for unicamente um assunto das ciências sociais que constatam e explicam, não pode resultar qualquer direito. Só o estabelecimento de uma norma fundamenta a diferença entre direito e não direito, mas não a natureza. O Sol brilha sobre justos e injustos.

Se o direito puder ser extraído de factos, não há qualquer direito. Os dois mundos estão contrapostos um ao outro; que o enunciado de que todo o direito é apenas poder possa ser exatamente invertido na tese de que todo o poder é apenas direito não prova uma conexão nem uma derivabilidade, mas a não unificabilidade. Se agora o direito receber o seu ritmo próprio, se as suas normas tiverem de ser válidas, numa completude sem buracos, independentemente de qualquer empiria, também nunca se poderá submeter ao direito para julgamento um Faktum empírico enquanto tal, isto é, há no direito apenas substâncias factuais e características de substâncias factuais, mas não factos singulares enquanto tais. Mesmo a palavra que ocorre numa determinação legal positiva transforma o acontecimento real que é dado a uma qualificação jurídica numa substância factual tal como o que é pressuposto pelo direito; no que se dá, talvez, que, se uma 
tal substância factual não se nos deparar, termina também logo o julgamento jurídico e o "caso" já não é tomado em consideração. A "situação dada" não é, em nenhum caso, julgada pelo juiz como apenas dada, a relação lógica tem aqui os seus reflexos empírico-psicológicos: o juiz não pode assumir nenhuma substância factual sem que lhe "ocorram" já, ou sejam mais ou menos conscientes, leis que devem encontrar aplicação. Cada apresentação de processos e acontecimentos, cada referência objectual que penosamente evita uma reflexão jurídica, só pode ser levada a cabo, apesar disso, segundo uma clareza esgotante sobre as possibilidades dos julgamentos jurídicos. Daí que a substância factual signifique já o resultado de uma especificação através da qual é criada uma nova configuração, e só com esta substância factual é que o jurista tem a ver. $\mathrm{O}$ encerramento completo do mundo das normas jurídicas está, com isso, assegurado.

Para levar a uma formulação penetrante a controvérsia das opiniões, pode-se dizer que se contrapõe à concepção do direito como meio para outros fins a outra concepção que vê no direito um fim último. No entanto, por fim, em ambos os casos, deve-se compreender algo fundamentalmente diferente, porque um fim último que pretenda ser fim último segundo o seu conceito, e não meramente no caso concreto, é precisamente algo essencialmente diferente do que um fim que se insira no infindo mecanismo entre fins e meios. A oposição não se encontra no que é psicológico, naquilo que os homens visam, pois então ele só significaria que, por um lado, há homens que se servem do direito (isto é, das representações dos homens a que se chamam jurídicas) como um meio, e que, por outro lado, pelo contrário, há homens para os quais o direito é o fim do seu poder como meio. Com isso, a questão tornar-se-ia uma questão histórica e a sua decisão tornar-se-ia dependente daquilo que os homens, numa situação concreta, teriam como o mais importante ou tomariam como o mais paradigmático. No entanto, se o fim for destacado deste contexto daquilo que é factual como fim último, como fim absoluto, ele deixa de ser fim de homens concretos, e surge, ao invés, uma série de sujeitos construídos deste "fim", os quais, no 
entanto, não podem usar quaisquer meios, posto que são pensados como realidades atuantes. Nomeadamente, quem, contra a tese de que o direito é apenas meio do poder estabelecer o enunciado de que o poder é apenas meio do direito vê no direito um poder supraempírico que põe o empírico ao serviço dos seus fins. Se o direito for o fim e o poder um meio de o efetuar, então o direito pode surgir do poder, quando o enunciado de que o poder é um meio do direito tornar o poder numa matéria a partir da qual o direito é formado. Se, pelo contrário, o direito, enquanto fim absoluto, nada tiver em comum com o meio, então nunca um meio pode corresponder ao fim, e não se consegue discernir porque aquele deve ser convocado para a definição do direito. Daí que o fim não faça parte da definição do direito.

O fim é determinado como algo que deve ser alcançado. Todo o antagonismo entre ser e dever-ser é mantido ainda de modo não esclarecido na expressão "deve ser alcançado". Pode-se dizer com isso que alguém, um sujeito concreto, quer alcançar algo que, visto a partir dele, é o fim, nomeadamente aquilo que deve ser alcançado; assim, por exemplo, no caso singular e de um modo geral, o saciar-se é o fim do comer; - ou há no "dever-ser" um reconhecimento, de tal modo que, segundo esta explicação, o fim é algo do qual se tem de exigir que seja alcançado. Nesta distinção torna-se patente o carácter insuficiente da definição do direito enquanto querer, enquanto fim. O normativo que se encontra nas palavras "deve ser efetivado" contém, designadamente, apenas uma remissão ao direito e não diz outra coisa senão que o direito é algo que deve ser efetivado com direito. A acentuação encontra-se no normativo, na legitimação do fim, não se trata, portanto, do fim, mas da norma. Uma assunção do fim significa a inclusão da efetivação do direito na sua definição, com o que se alcança um momento da realidade e, para usar a formulação de antíteses, um momento do poder na definição de uma norma pura, independente de qualquer facto e experiência. A norma não pode transportar qualquer querer, qualquer fim; o portador de um fim só pode ser uma realidade que talvez veja a sua tarefa na "efetivação" do direito, mas que, precisamente por isso, deve ser con- 
ceptualmente separado do direito, de modo rigoroso, enquanto se falar de fim. A pergunta pelo fim não é a pergunta pela essência do direito, mas a pergunta pelo sujeito do ethos que se pode encontrar no direito. A norma está acima do mecanismo de meio e fim, mas o mundo empírico pode ser o meio do direito no sentido de um medium, na medida em que nele deve ser efetivado um estado que tenha de ser designado como conforme ao direito, e isso através de um poder que se pode designar como conforme ao direito. No entanto, definir o direito como fim ou querer não conduz a nada senão a dar entrada ao pensamento da segurança, no seu significado mais material, e a fazer do direito não certamente um meio, como quer uma teoria do poder falsificada, mas um fim que, na melhor das hipóteses, é metodicamente homogéneo ao meio, neste sentido. Isso é válido, nomeadamente, quando a segurança, por seu lado, novamente, deve ser as "condições externas" de uma vida ética dos indivíduos, e o direito, enquanto conteúdo das condições externas, deve tornar-se meio para este fim.

Em cada remissão a uma vontade, a algo que deve ser efetivado, encontra-se um quebrar-se da fronteira que separa o direito da efetividade, uma inconsequência que confunde e obscurece. Pois a vontade só pode aqui significar um fenômeno que não pertence ao direito, mas ao ser. $\mathrm{O}$ direito, enquanto vontade que deve ser efetivada, não quer dizer outra coisa senão uma norma que deve tornar-se um estado, ou seja, que deixa de ser uma norma, para se tornar recebida pelo querer empírico dos homens. Como, para o direito, não há nenhum outro mundo senão o do direito, e como a força expansiva da valoração jurídica conquista qualquer objeto que é posto em relação com o direito, para o tornar num objeto de valoração jurídica quando este não o puder ignorar, o direito não pode querer efetivar-se a partir dele mesmo. Enquanto se tratar deste mundo do direito, é válido, na verdade, o enunciado que, hoje ainda, numa confusão de leigos, se ouve estabelecer como a lei positiva, o de que no direito não há nenhum espaço sem direito. O império do direito não tem quaisquer fronteiras fácticas, pois a factualidade tem apenas fundamento e consequência, mas não valores, não um acima e um abaixo. 
Aqui é preciso salientar um curso de pensamento óbvio, elementar, cuja plenitude de significação para o conhecimento do direito permaneceu sem atenção, tal como muita coisa que tem de ficar atrás das curiosidades que se destacam: a circunstância de que, através do direito, cada canalha é posto em vantagem à medida que a sua injustiça tem primeiro de ser provada, mas que esta prova resulta de homens que se referem ao direito e, nessa medida, são seus adversários. No entanto, qualquer homem "normal" exige que apenas homens "normais" o coloquem a juízo, e cada um conhece o carácter ridículo da argumentação de um criminoso que queira fazer válido que "com o mesmo direito" imputa crimes aos seus juízes. Se o homem que está no seu direito quiser ser julgado pelos seus "pares", então a igualdade volta a ser subtraída ao direito e, do mesmo modo, dá-se a partir das valorações do direito, a partir de que este conhece um acima e um abaixo e não conhece nenhuma outra consequência que não a adequação ao direito, que, para o anormal em sentido jurídico, já não há essa igual legitimação. $\mathrm{O}$ fundamento não está em que apenas o homem normal se "sabe introduzir na psique do outro homem", mas na estrutura interna deste império do direito, que só consegue reconhecer as suas normas próprias.

Em geral, considera-se o direito como algo que se refere à vida conjunta exterior dos homens. É-lhe atribuída até habitualmente, como marca de diferenciação em relação à ética, uma tendência à coação, ou seja, à intervenção no mundo dos fenômenos e realidades. Tais explicações do direito contêm, no entanto, uma determinação contraditória. Um complexo de normas de cuja essência faz parte ter uma "tendência à coação" seria um par de coisas heterogêneas, pois a norma mantém-se independentemente da efetividade, e assim mantém também a sua validade e o seu valor independentemente da efetivação e da coação. Que a norma se refira apenas a um comportamento "exterior" dos homens, que esteja orientada para uma visibilidade, nada tem a ver com a coação. Aquilo de que a norma faz a sua substância factual, que ela ignore acontecimentos internos, puramente psicológicos, na medida em que não sejam reunidos com um acontecimento exterior, 
“objetivado", enquanto aquilo a que a norma encontra aplicação, não pode ser confundido com aquilo no qual deve haver uma real intervenção. A norma não pode ser sujeito de uma intervenção, ou efetivação e, com isso, não pode ser sujeito de um querer, não pode ser portadora de um fim; o direito não é vontade, mas norma, não é um comando, mas um mandamento, face ao qual o homem singular, enquanto objeto do mundo da efetividade, chega tarde de mais. Se, apesar disso, o direito tem uma relação particular à efetividade, ao "mundo", e se - para o antecipar - recebe, através disso a sua autonomia não derivável em relação à ética, então é precisa o uma reflexão particular sobre em que consiste a particularidade da relação. $\mathrm{O}$ direito é pensamento abstrato que não é extraído de factos e não pode intervir sobre factos, e só uma realidade pode ser sujeito do querer orientado para a "efetivação" do direito. O problema consiste em ligar os dois reinos um ao outro, em mediar o ponto a partir do qual - conservando o primado do direito face ao poder - se execute sobre o ser uma intervenção no sentido das normas jurídicas. 